\title{
湧水量が低下する海底トンネルの力学的安全性 に関する基礎的研究
}

\author{
西藤潤 1 丹生和宏 ${ }^{2} \cdot$ 岸田潔 ${ }^{3} \cdot$ 深沢成年 $^{4}$ \\ ${ }^{1}$ 正会員 京都大学准教授 工学研究科社会基盤工学専攻 （ $\bar{T}$ 615-8540 京都府京都市西京区京都大学桂 $\mathrm{C} 1$ ） \\ E-mail: saito.jun.3n@kyoto-u.ac.jp \\ 2 正会員 パナソニック（广 571-8501 大阪府門真市大字門真 1006 番地） \\ 3 正会員 京都大学准教授 工学研究科都市社会工学専攻 ( $\bar{T}$ 615-8540 京都府京都市西京区京都大学桂 $\mathrm{C} 1$ ) \\ ${ }^{4}$ 正会員 鉄道・運輸機構設計技術第二課長（广 231-0005 横浜市中区本町 6-50-1）
}

\begin{abstract}
現在, 海底トンネルで坑内湧水量が減少する事例が報告されている. 海底トンネルの坑内湧水量が減少するこ とは維持管理の観点からすると好ましいことである. しかし，トンネルおよびその周辺地盤に対して作用する 水圧状態などが変化することが考えられ，トンネルの健全性への影響について検討することが求められる. そ こで本論文では, 周辺地盤の透水性変化がトンネルに及ぼす影響についてモデル化を行い, 数值計算による検 討を行った. その結果, 透水性の低下によって周辺地盤の間隙水圧分布の変化, 塑性領域の拡大などが生じる 場合があることを確認した.
\end{abstract}

Key Words : undersea tunnel, finite element method, permeability decrease, seepage water

\section{1. 諸言}

\section{(1) 研究の背景}

一般に海底トンネルにおいては，その施工および維 持管理について, 膨大な量の涌水とそれに伴うトンネ ル周辺に作用する大きな間隙水圧の対策が最大の課題 となる．とくに，青函トンネルは海面下約 $240 \mathrm{~m}$ に位 置し, 最大約 $2400 \mathrm{kPa}$ もの間陌水圧が作用する. 青函 トンネルの地山は新第三紀中新世で, 固結度の低い凝 灰岩類の薄層を挟在する砂質泥岩からなる軟弱地盤と なっている. そのため, 掘削およびトンネル施工時に は, 膨大な量の湧水と大きな間隙水圧の対策として薬 液注入工法が採用された ${ }^{11}$. 間隙水圧はこの注入域の外 周に作用し，この領域を浸透した湧水は覆工背面で導 水され, 覆工自体には直接間隙水圧が作用しないよう な設計となっている.

現在, 青函トンネル全体の揚水量は, 1988 年から 2005 年にかけて約 18\%, 青函トンネルの本坑 (海底部) では 1989 年から 2005 年にかけて約 23\%の揚水量の減少が 報告されている $\left(\right.$ 図-1 ${ }^{2)}$. トンネルの維持管理という観 点では, 涌水量の低下は好ましいことである．浸透す る水量が減少している要因の 1 つとしてとして, 水み ちの目詰まりなどによるトンネル周辺での透水性の低 下が考えられる. 透水性の低下はトンネル周辺の間隙 水圧分布に影響しているため, 前述したように覆工に は直接間隙水圧が作用しない設計になっているものの, 場合によっては周辺の間隙水圧がトンネルの健全性に

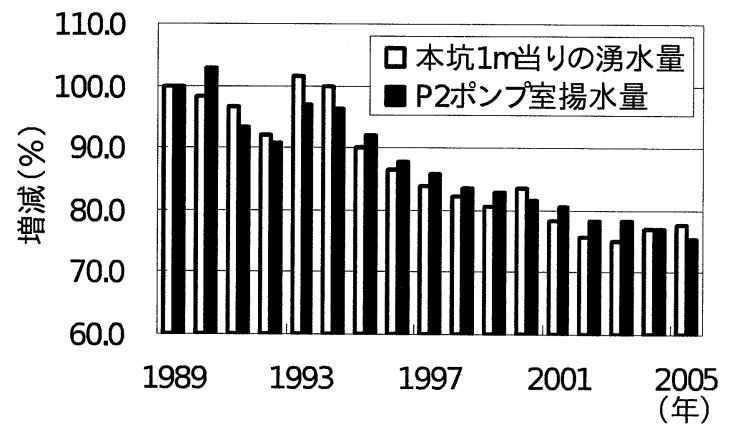

図-1 青函トンネル (本坑) 海底部での $1 \mathrm{~m}$ 当りの湧水量とポ ンプ揚水量 ${ }^{2)}$

悪影響を及ぼす可能性もある.

この課題について, 土谷ら ${ }^{2)}$ は, 青函トンネル本坑に おいて行われている長期計測結果を整理し, 分析を行っ ている. また, 湧水量の変化がトンネルの挙動に及ぼ す影響を数值解析により検討している. その結果, 涌 水量低下の原因が注入域の透水性低下とした場合は覆 工の健全度は確保されるが, 覆工背面の導水機能低下 が要因であった場合, 覆工の健全性に問題が生じる可 能性があることを指摘している．また，丹生ら ${ }^{3)}$ は覆工 背面で透水性が著しく低下することを想定し, 数值解 析による検討を行った. 解析の結果, トンネル覆工と 周辺地盤の間に剥離が生じる可能性があることを言及 し, 透水性低下が海底トンネルの安全性に影響を与え 得ることを示した.これらの研究では, ある程度の定 性的な評価はできているものの, 数值解析において簡 
表-1 解析に用いた物性值

\begin{tabular}{c|c|c|c}
\hline & 覆工 & 注入域 & 非注入域 \\
\hline Young 率 $[\mathrm{kPa}]$ & $3.0 \times 10^{7}$ & $3.0 \times 10^{5}$ & $3.0 \times 10^{5}$ \\
\hline Poisson 比 & 0.20 & 0.33 & 0.33 \\
\hline 透水係数 $[\mathrm{m} / \mathrm{s}]$ & - & $1.0 \times 10^{-8}$ & $1.0 \times 10^{-6}$ \\
\hline 粘着力 $[\mathrm{kPa}]$ & $5.0 \times 10^{4}$ & $5.0 \times 10^{2}$ & $5.0 \times 10^{2}$ \\
\hline 内部摩擦角 & $50^{\circ}$ & $30^{\circ}$ & $30^{\circ}$ \\
\hline ダイレイタンシ角 & $40^{\circ}$ & $20^{\circ}$ & $20^{\circ}$ \\
\hline $\begin{array}{c}\text { 単位体積重量 } \\
{\left[\mathrm{kNN} / \mathrm{m}^{3}\right]}\end{array}$ & 25 & 20 & 20 \\
\hline
\end{tabular}

単なモデル化を行っていること，得られたデータを利 用していないことから，定量的な評価は出来ていない。

そこで, 本研究では将来の健全性評価を適切に行う ため, 涌水量の減少量をもとに，周辺地盤の透水性低 下をモデル化し, トンネルの力学的挙動を調べる. 周 辺地盤での透水性変化のパターンとして 3 つのケース を想定し, 覆工に生じる応力状態の変化やトンネル周 辺の水圧分布の変化について調べ，その結果をもとに 健全性の評価を行う。

\section{2. 数值解析}

\section{(1) 解析条件}

本研究では, 図-2 のような海面下 $240 \mathrm{~m}$, 海底下 100 $\mathrm{m}$ に馬蹄形トンネルが存在する領域を考え，対称性か ら右半分のみを解析領域とした．解析に用いた有限要 素メッシュを図-3に示す. 図-3(a) に示すように，解析 領域の大きさは縦 $140 \mathrm{~m}$ ，横 $90 \mathrm{~m}$ とした. この領域は, 予備的な解析により，トンネル近傍の力学的評価に影 響を与えない十分な大きさであることを確認している。 また，掘削時に止水のために薬液を注入した領域の半 径は $15.4 \mathrm{~m}$ とした ${ }^{1) 4}$. 全要素数は 2492 , 全節点数は 2606 である. 図-3(b) は，覆工付近の有限要素メッシュ である. 覆工は不透水性で, 厚さは $0.7 \mathrm{~m}$ であり, 内側 4 層 (要素数 168) が覆工に相当する. 境界条件は上側を 自由表面，左右両側および下側をスライダー支持とし た．水理境界条件は，上側，右側，下側を排水境界と し，左側を対称軸として非排水境界としている.

トンネル覆工および周辺地盤は弾完全塑性体として 考え，2 次元平面ひずみ条件下において，土一水連成有 限要素解析を行う．解析では, Biot の圧密方程式と完 全弾塑性体の応力ひずみ関係式をもとに定式化を行う. 降伏関数には Mohr-Coulomb の降伏規準を用い, 塑性 ポテンシャルには Drucker-Pragar の降伏規準を用いる 非関連流れ則を使った ${ }^{5)}$. 時間方向の積分に関しては後 退差分を用いる．また，本研究で用いた物性值は既往 の文献6)7)を参考にして決めた（表-1 参照）.

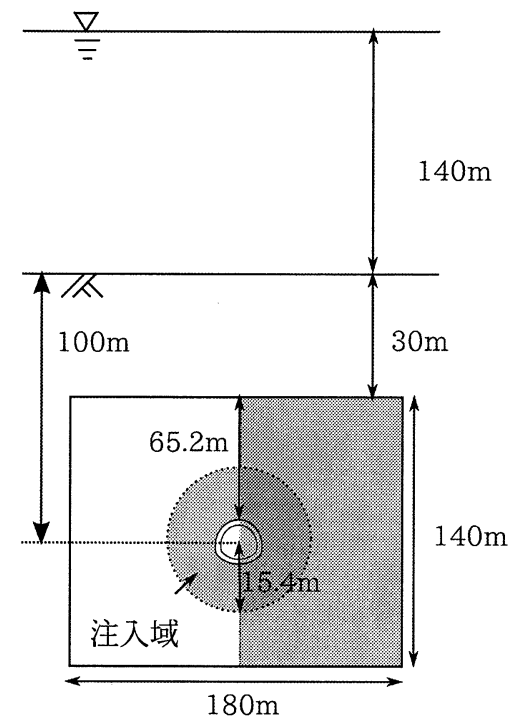

図-2 解析領域

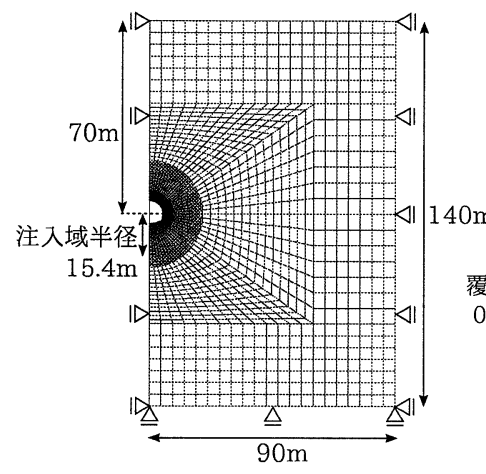

(a) 覆工付近の領域

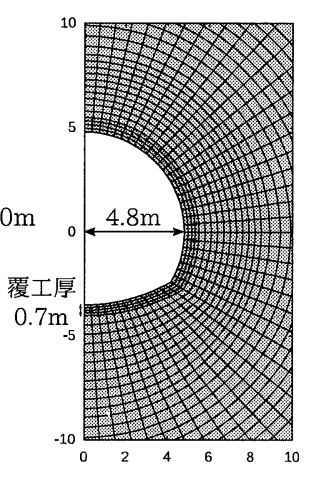

(b) 全体図
図-3 解析に用いた有限要素メッシュ

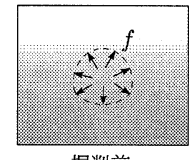

掘削前

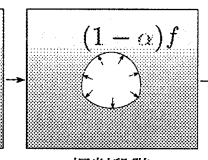

掘削段階

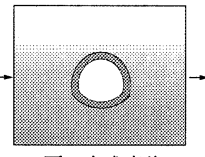

覆工完成直後

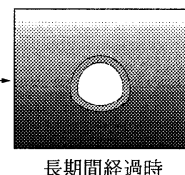

長期間経過時
図-4 解析の手順

\section{(2) 解析の順序}

解析はトンネルの施工過程を踏まえ，図-4に示すよ うに (a) 掘削段階，(b) 覆工完成直後，(c) 長期間経過時 の 3 段階に分けて計算を行う ${ }^{8) 9}$. 以下, 各段階につい て説明を行う。

\section{a) 掘削段階}

土被りは $100 \mathrm{~m}$ と大きいため, 掘削前の地盤には等 方的な全応力が作用しているとする．掘削段階では掘 削相当外力 $f$ を応力解放係数 $\alpha(0<\alpha<1)$ の分だけ解 放させる ${ }^{10)}$ ．青函トンネルは主に NATM 工法で建設さ れており，地盤の緩みを許容しつつ，施工された．その ため，地山から覆工に作用する荷重は大きく軽減され 
ているので, 本研究における応力解放率は $95 \%(\alpha=0.95)$ とする.

\section{b) 覆工完成直後}

覆工を建設した後, 掘削が進むことで, 解析の対象 となる平面内において周辺地盤が緩む. これにより, 覆 工に $(1-\alpha) f$ の力を分担させる.

\section{c) 長期間経過時}

揚水量低下を鑑み，経年とともにトンネル周辺地盤 の透水性を低下させるモデルを考える．透水性低下の 要因として，以下に示す 3 つのケースを想定する.

ケース 1 ：注入域の一部における透水性の低下

覆工に向かって流れ込む海水に含まれる細粒分が 注入域の覆工背面側から非注入域側へ向かって目 詰まりを起こし, 注入域の一部で透水性が低下す る (図-5(a)).

ケース 2 : 非注入域の一部における透水性の低下

覆工に向かって流れ込む海水に含まれる細粒分が 注入域と非注入域の境界から外側に向かって目詰 まりを起こし，非注入域の一部で透水性が低下す る (図-5(b)).

ケース 3 : 注入域の全体における透水性の低下

掘削時の止水のため注入された薬液と海水が化学 変化を起こした結果, 注入域全体で一様に透水性 が低下する (図-5(c)).

\section{(3) 経年変化による透水係数の設定}

青函トンネルの湧水量は 1988 年から 2010 年までの 約 20 年で約 $23 \%$ ぼ減少していることが報告されてい る. そこで, 本研究では 20 年間で約 $25 \%$ 減少するよう 透水係数を低下させる. さらに将来の健全性評価も行 うため, その後さらに 20 年経過して涌水量が約 $40 \%$ ま で減少することを想定し，透水係数を低下させる．透 水係数の低下率は, 透水係数の低下率を試行錯䛊的に 変化させ, 順解析を複数ケース行うことで, 同定した.

ケース 1 では, 60ケ月でメッシュ 1 層分 $(0.3 \mathrm{~m})$ の透水 係数を $k_{1}=1.0 \times 10^{-8}[\mathrm{~m} / \mathrm{s}]$ から $k_{1}^{\prime}=3.5 \times 10^{-9}[\mathrm{~m} / \mathrm{s}]$ まで低下させる (図-6). 1 層分透水性が $k_{1}^{\prime}$ まで低下し たら, 同様にその外側の 1 層の透水性が $k_{1}$ から $k_{1}^{\prime}$ ま で低下する. 上記の手順を 8 層分, つまり 40 年分行う. 透水係数の低下する層の長さは $2.4 \mathrm{~m}$ である. 透水性が $k_{1}^{\prime}$ までしか低下させない，これは, 地盤の間隙は有限 領域であり，ある程度まで詰まるとそれ以上は間隙に 細粒分が詰まらず，透水性も低下しないためである．な お, 各要素での透水係数 $k_{v}$ は, 時間に関して線形的に 変化するわけでなく, 以下の式から計算する.

$$
k_{v}=\frac{d}{x / k_{1}^{\prime}+(d-x) / k_{1}}
$$

この式は, 図-7に示すように, 水の流れに対して垂直

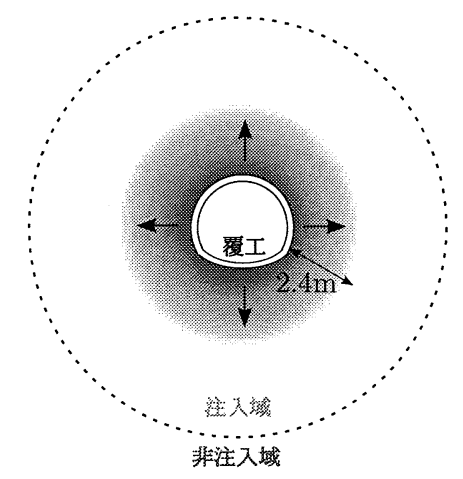

(a) 注入域の一部における透水性低下領域の拡大

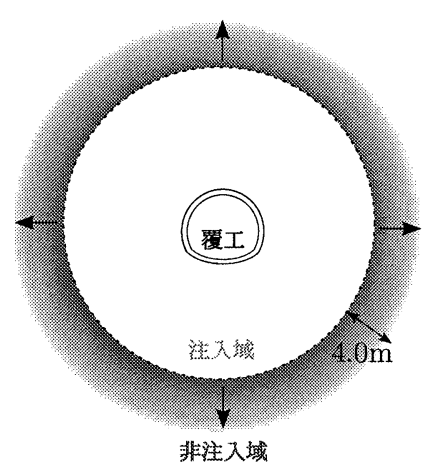

(b) 非注入域の一部における透水性低下領域の拡大

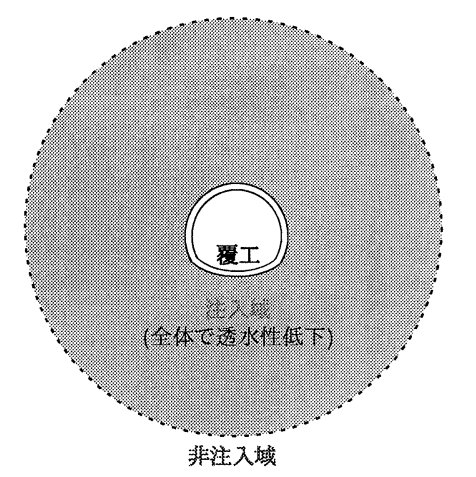

(c) 注入域の全体における透水性低下

図-5 透水性が低下する領域

に，異なる透水係数を持つ領域が層をなしているとき の平均的な透水係数の值を表している. ここで, $d$ は要 素の厚さ, $x$ は要素内において透水性の低下した層の厚 さ， $k_{1}$ は透水性が低下する前の透水係数， $k_{1}^{\prime}$ は透水性 が低下した後の透水係数である (図-7). なお, 透水性が 低下する層厚 $x$ は時間に関して線形関係にあるとする.

ケース 2 においては，60ケ月でメッシュ 1 層分 $(0.5 \mathrm{~m})$ の透水係数を $k_{2}=1.0 \times 10^{-6}[\mathrm{~m} / \mathrm{s}]$ から $k_{2}^{\prime}=3.0 \times$ $10^{-9}[\mathrm{~m} / \mathrm{s}]$ まで低下させる (図-8). 1 層分透水性が低下 したら, 同様にその外側の 1 層の透水性が $k_{2}$ から $k_{2}^{\prime}$ ま で低下する.この手順を 8 層分, 40 年分行う. 透水係 数の低下する層は $4.0 \mathrm{~m}$ である. 透水性が $k_{2}^{\prime}$ まで低下 すると，それ以上は低下させない，これはケース 1 と 


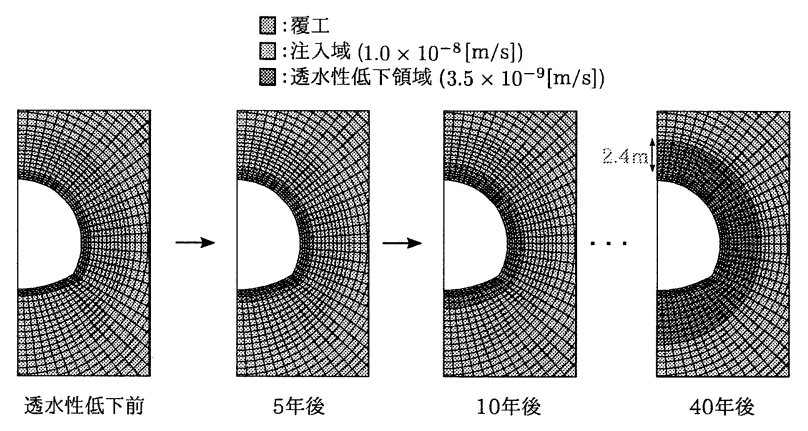

図-6 ケース 1 の解析の流れ

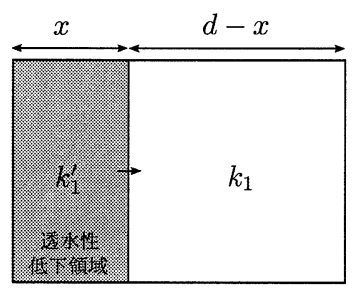

図-7 1 要素内での透水性低下のモデル

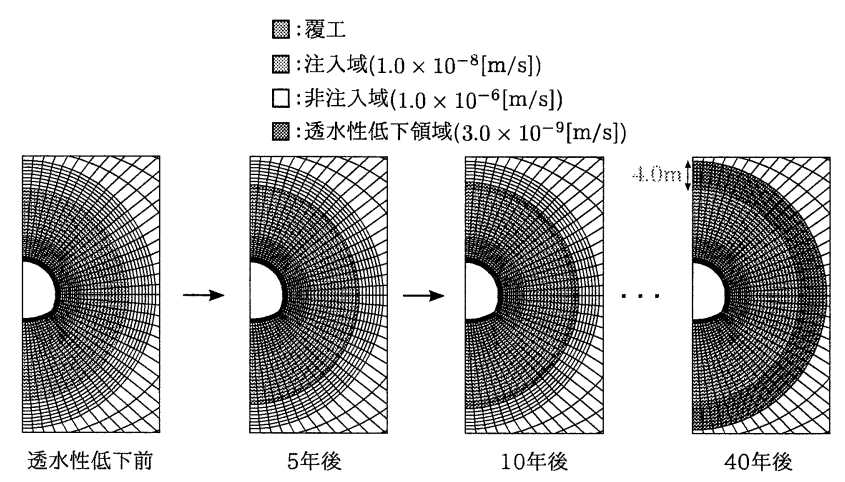

図-8 ケース 2 の解析の流れ

同様の理由による.この場合における透水係数も，式 (1)に従って減少するものとする.

ケース 3 においては，最初の 20 年間は，注入域全体 で一様に透水係数を $k_{3}=1.0 \times 10^{-8}[\mathrm{~m} / \mathrm{s}]$ から $k_{3}^{\prime}=$ $7.5 \times 10^{-9}[\mathrm{~m} / \mathrm{s}]$ まで低下させる．簡単のため，透水係 数の減少は時間に関して線形とする (図-9). 20 年経過 時から 40 年経過時までは注入域全体で一様に透水係数 を $k_{3}^{\prime}=7.5 \times 10^{-9}[\mathrm{~m} / \mathrm{s}]$ から $k_{3}^{\prime \prime}=6.0 \times 10^{-9}[\mathrm{~m} / \mathrm{s}]$ ま で1ヶ月ごとに線形的に低下させる(図-9).

\section{3. 解析結果}

数值解析においては, トンネル周辺地盤の要素で透 水係数を低下させ，それに起因するトンネル周辺の水 圧分布, トンネル覆工の応力状態, 周辺地盤の応力状 態, 塑性領域の変化を調べた. 以下, 項目別に各ケー スの結果を述べる.
土木学会論文集F1 (トンネル工学), Vol. 67, No. 3, I_25-I_32, 2011.

\section{물:覆工}

四圆圆圆: 注入域 $\left(1.0 \times 10^{-8}[\mathrm{~m} / \mathrm{s}] \sim 6.0 \times 10^{-9}[\mathrm{~m} / \mathrm{s}]\right)$ 口:非注入域 $\left(1.0 \times 10^{-6}[\mathrm{~m} / \mathrm{s}]\right)$
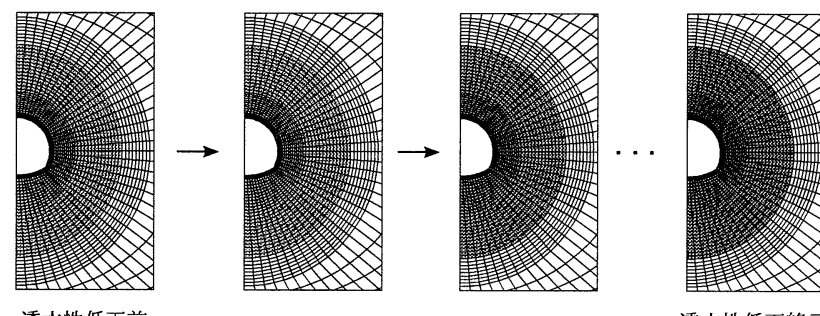

透水性低下終了

図-9 ケース 3 の解析の流れ

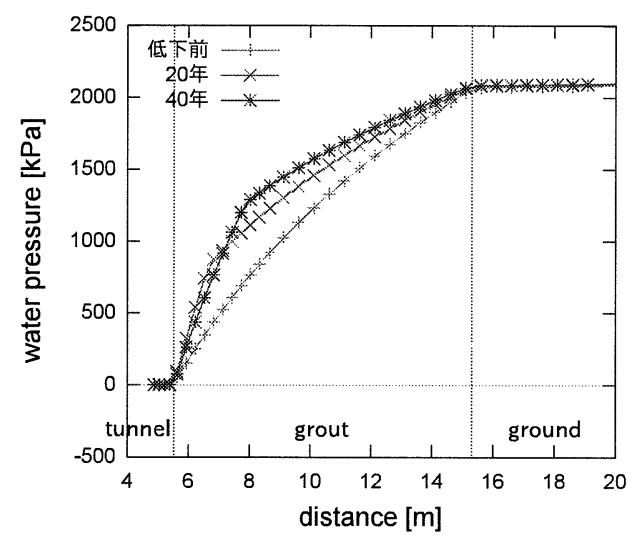

図-10 水平方向の間隙水圧分布 (ケース 1)

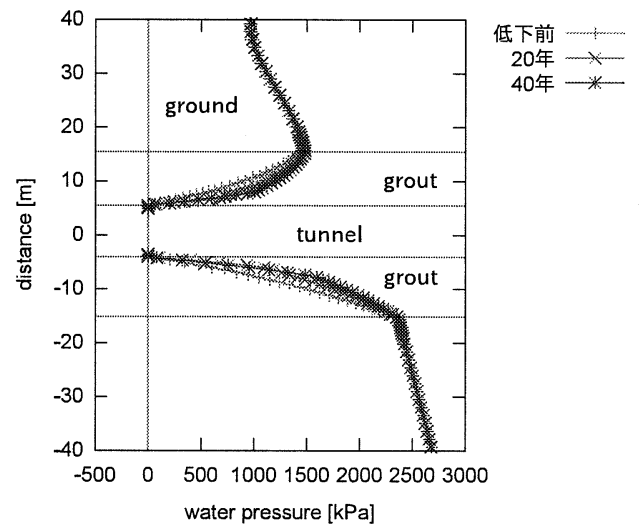

図-11 鉛直方向の間隙水圧分布 (ケース 1)

\section{(1) 間隙水圧分布}

ケース 1 の解析によって得られた間隙水圧の分布を 図-10, 図-11に示す. 図-10 は横軸にトンネルから水平 に右側に進んだ距離をとり，縦軸に間隙水圧をとる. 図11 は縦軸にトンネルから鉛直上向きに進んだ距離をと り，横軸に間隙水圧をとる. 2 つ図から分かるように 20 年経過時と 40 年経過時で間隙水圧の分布は大きく 変化していない.これより, 透水性の低い領域が注入 域内である程度まで拡大すると，透水性が低下してい る領域の外周に作用する間隙水圧の值が変化しないこ とが分かる.

ケース 2 の解析によって得られた間隙水圧の結果を 


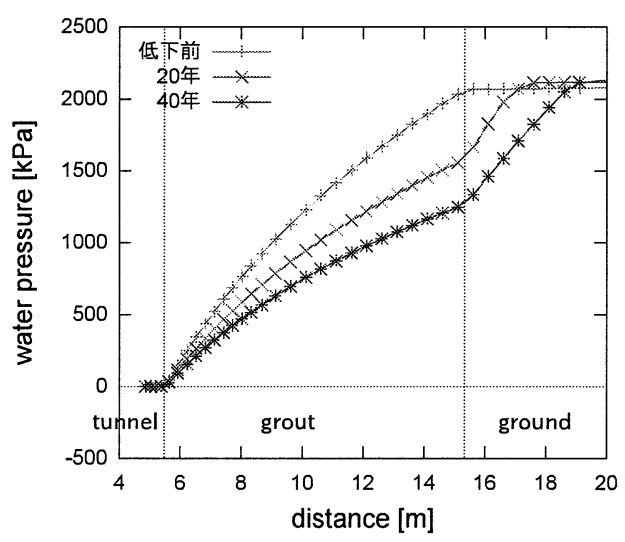

図-12 水平方向の間隙水圧分布 (ケース 2)

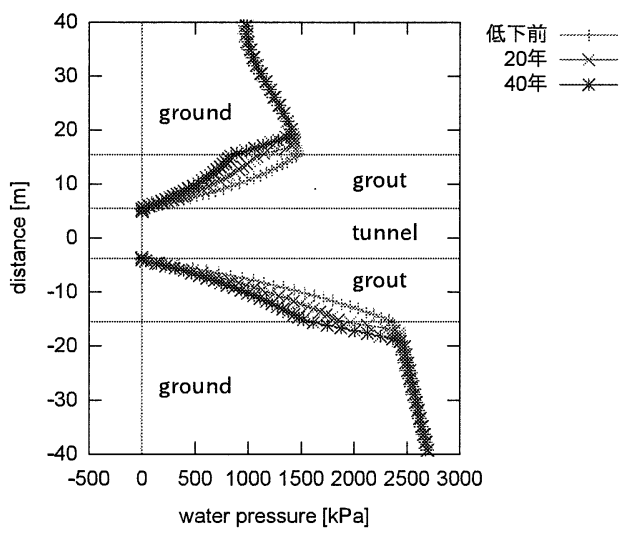

図-13 鉛直方向の間隙水圧分布 (ケース 2)

図-12, 図-13 に示す. 非注入域の透水性が低下するに したがって，注入域内の間隙水圧は低下している。 ま た, 間隙水圧の低下は透水係数が低下する領域におい て生じている.これは, 注入域の外側で透水係数が低 下するため, 透水係数の低い注入域の領域が拡大した ような状態とみなすことができる.

ケース 3 では間隙水圧分布の変化はほとんど見られ なかった.これより, 透水係数が注入域で一様であれ ば，大きさによらず，注入域外側と覆工の水頭差で間 隙水圧分布が決まることを確認した。

\section{(2) トンネル覆工の応力経路}

ここでは, 図-14に記したトンネル覆工の代表的な要 素 1 10における応力経路を MIT 法により, $(p, q)$ 面上 に表した図を示す.ここで $p, q$ は, 最大主応力 $\sigma_{1}^{\prime}$ およ び最小主応力 $\sigma_{3}^{\prime}$ を用いて以下のように表される.

$$
p=\frac{\sigma_{1}^{\prime}+\sigma_{3}^{\prime}}{2}, \quad q=\frac{\sigma_{1}^{\prime}-\sigma_{3}^{\prime}}{2}
$$

ケース 1 の覆工の応力経路を図-15 に示す. 応力経路 の変化が大きなものには，矢印を付した．応力があま り変化していない経路には矢印を付していない. 図-15 から分かるように，すべての要素で塑性化せず，破壊
土木学会論文集F1 (トンネル工学), Vol. 67, No. 3, I_25-I_32, 2011.

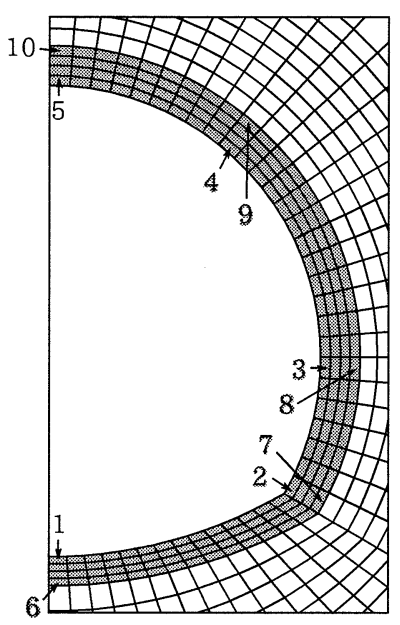

図-14 トンネル覆工の代表的な要素

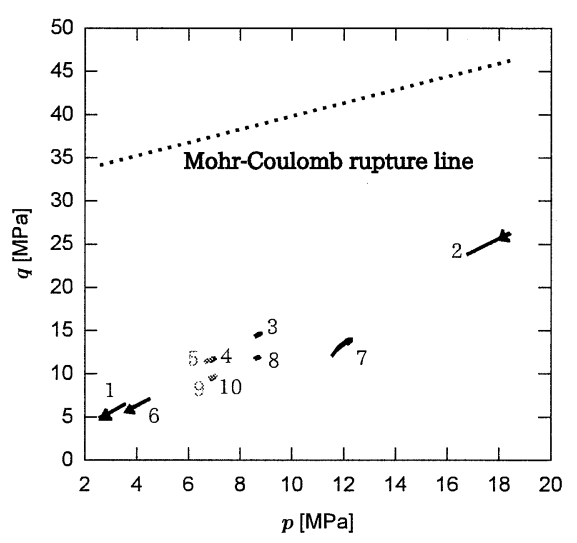

図-15 覆工の応力経路 (ケース 1)

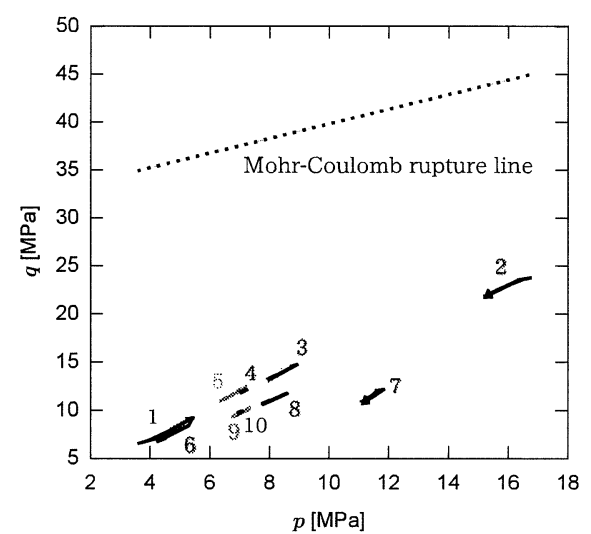

図-16 覆工の応力経路 (ケース 2)

線にも近づいていない，つまり応力経路から，覆工の 応力はあまり変化していないことが分かる.

ケース 2 の覆工の応力経路を図-16に示す. 図-16を 見ると, ケース 2 においても，すべての要素で塑性化 せず，破壊線にも近づく傾向は現れていないことが分 かる. よってケース 2 の場合も, 覆工の応力はあまり 変化していないと言える. 


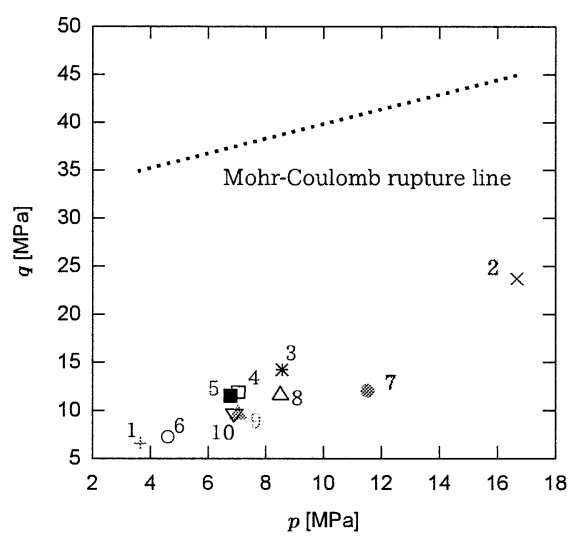

図-17 覆工の応力経路 (ケース 3)

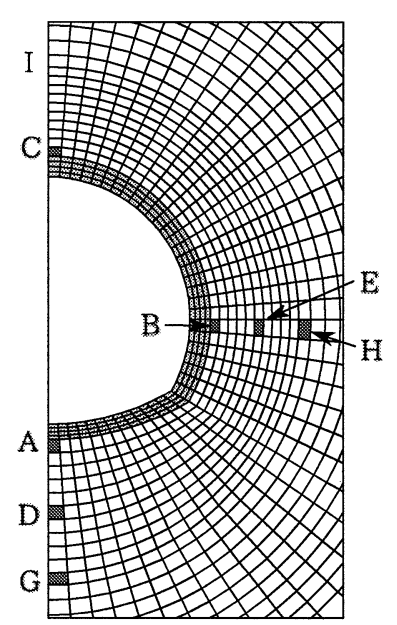

図-18 トンネル周辺の代表的な要素

ケース 3 の覆工の応力経路を図-17 に示す.この場合, 応力経路の変化がケース 1 およびケース 2 に比較して, ほとんど生じないので, 点を付して表した. 覆工の応 力経路に変化がないのは, 周辺地盤での間隙水圧がわ ずかずつしか増加しておらず，覆工にほとんど影響を 及ぼさないためである.

以上，3つのケース全てにおいて，覆工に関しては透 水係数の低下によって大きな影響はないことが分かった.

\section{(3) 周辺地盤の応力経路}

ここでは, 図-18に示すトンネル周辺の代表的な要素 A I における応力経路を $(p, q)$ 面上に表す. ここで $p, q$ は式 (2)に示した式と同様である.

ケース 1 における応力経路を図-19 に示す. 各応力経 路の終着点には, 矢印を付してある.

覆工に近く, 透水性低下前に既に塑性化している要 素 A〜F は，しばらく塑性状態を継続していたものの， 最終的には弾性域に戻ってきていることが分かる。 こ れは，透水性低下領域が広がるにつれて間隙水圧が増 加傾向から減少傾向に移行し，その分有効応力が増加
土木学会論文集F1 (トンネル工学), Vol. 67, No. 3, I_25-I_32, 2011.

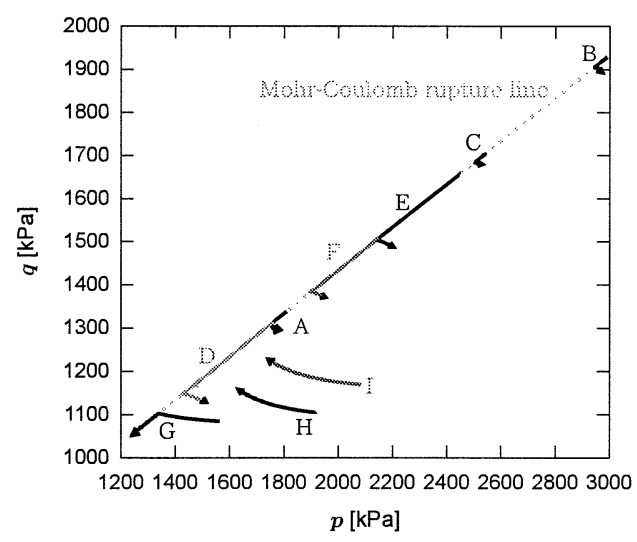

図-19 周辺地盤の応力経路 (ケース 1)

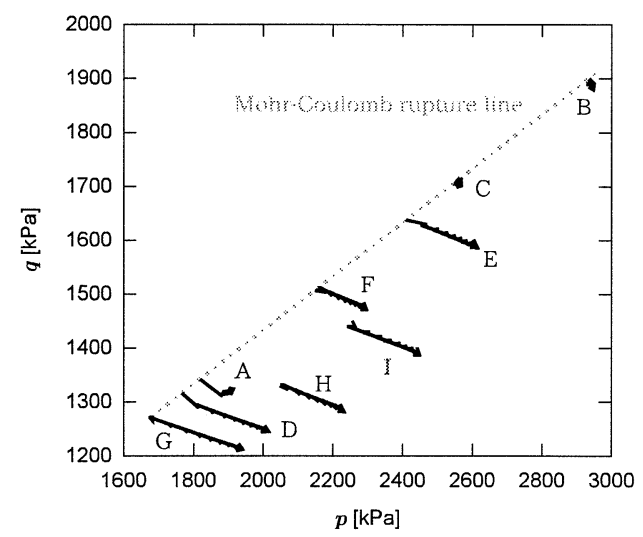

図-20 周辺地盤の応力経路 (ケース 2)

したためである.他方, 覆工から最も遠い要素 $\mathrm{G}$ は弾 性域にあったものの, 最終的に降伏した. 同様に覆工か ら最も遠い要素である $\mathrm{H}, \mathrm{I}$ は, 依然として弾性域のま まであるが，徐々に破壊線に近づいていることが分か る.これは透水性の低い領域が広がったことによって, 当該領域の外周で間隙水圧が上昇し, 有効応力が減少 したためと考えることができる.

ケース 2 における応力経路を図-20 に示す. 図-20を 見ると, すべての要素 A〜Iにおいて塑性域から弾性域 への移行が見られる。.これは，注入域の外周に透水性 の低下した領域が生じたことで，注入域が拡大したよ うな効果があるためと考えられる。つまり，拡大した透 水性低下領域の外周に大きな間隙水圧が作用すること により, 注入域での間隙水圧が低下し, その結果とし て有効応力が増加し, 破壊線から遠ざかっためである.

ケース 3 における応力経路を図-21に示す. 応力経路 の変化が少ないため, 矢印を付していない. 図-21を見 ると, A Iのすべての要素で応力経路はほとんど移動 していない，ケース 3 では透水性が注入域全体で一様 に低下しているため，注入域での間隙水圧もわずかず つしか上昇しない. そのため, 有効応力もほとんど変 化しないため応力経路も移動しないと考えられる. 


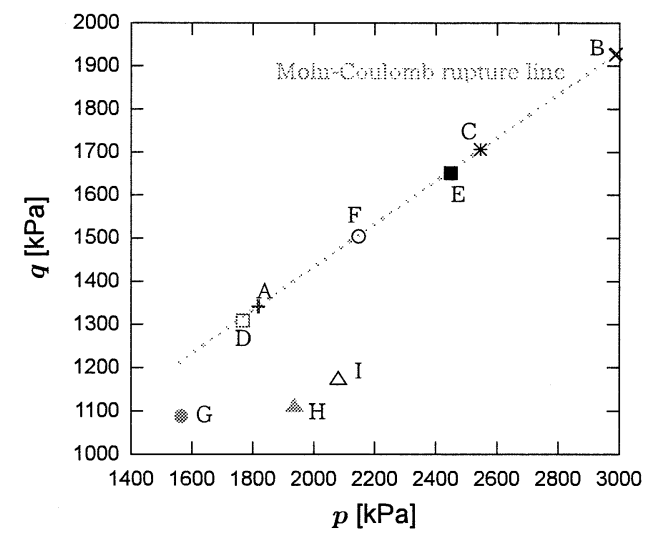

図-21 周辺地盤の応力経路 (ケース 3)

\section{涉弾性領域 \\ 들. 塑性化した領域}

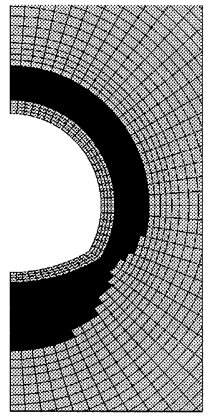

透水性低下前

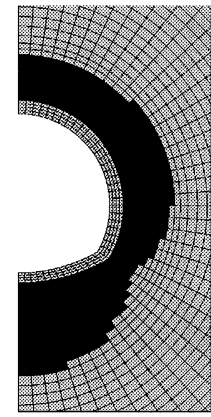

20 年経過時

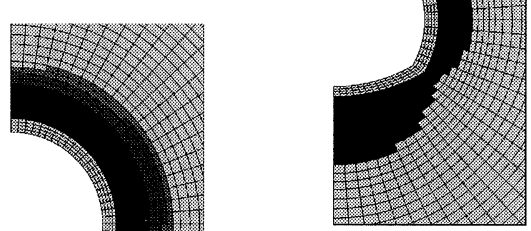

透水性低下前

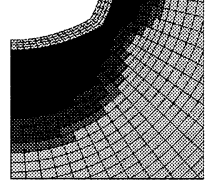

40 年経過時
図-22 塑性領域の拡大の様子 (ケース 1)

\section{(4) 塑性領域の拡大}

図-22 にケース 1 における塑性領域の拡大の様子を示 す. 青い色で示した要素が弾性領域で，その他の要素 が塑性領域である。注入域において透水性が低下する につれて, 塑性領域が拡大していることが分かる.こ れは透水性が低下し，間隙水圧が上昇することにより 有効応力が減少したため, 塑性に至ったと考えられる.

図-23 に，ケース 2 における塑性領域の拡大の様子を 示す. ケースでは, 周辺地盤の応力経路からも分かる ように, 応力は塑性領域から弾性領域に遷移する傾向 があり, 塑性領域の拡大は見られなかった.

図-24 に，ケース 3 に打塑性領域の拡大の様子を 示す，透水性の低下によって, 塑性領域はわずかに拡 大した. ケース 1 と異なり, 注入域の全体で一様に透 水性が低下した場合, 注入域内の間隙水圧もわずかに しか上昇せず, 有効応力もほとんど減少しないためで ある。

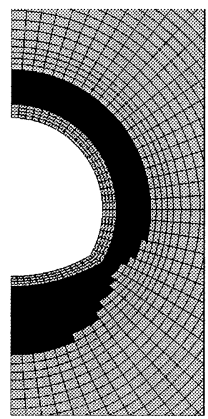

20 年経過時

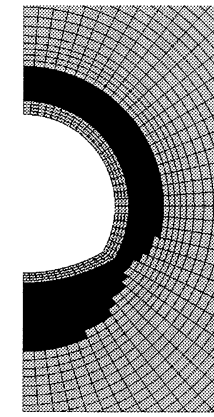

40 年経過時
図-23 塑性領域の拡大の様子 (ケース 2))

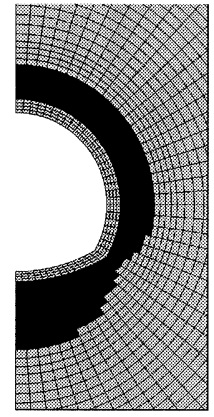

図-24 塑性領域の拡大の様子 (ケース 3)

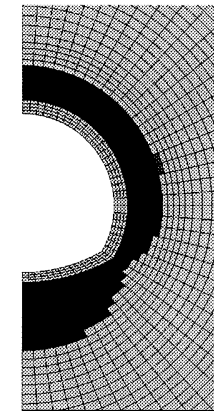

40 年経過時
土木学会論文集F1 (トンネル工学), Vol. 67, No. 3, I_25-I_32, 2011.

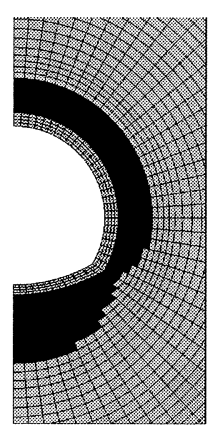

透水性低下前
20 年経過時

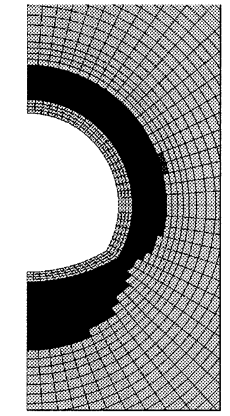

\section{4. 結言}

本研究では, 海底トンネルの周辺地盤での透水性低 下に起因する力学的挙動を調べるため数值シミュレー ションを行った．透水性が低下するケースとして $3 つ$ のモデルを想定した. 以下に，それぞれのケースで得 られた結論をまとめる.

注入域の一部での透水性が低下するケース 1 では, 透 水性の低下に伴い覆工周辺の間隙水圧が上昇すること を確認した. しかし透水性低下領域がある程度まで広 がると, 透水性が低下する領域では, 間隙水圧はあま り変化しないことが分かった. また, 間隙水圧が増加 しているときは, 有効応力の減少により塑性領域が広 がる.

非注入域の一部での透水性低下を想定したケース 2 では, 透水性の低下に伴い, 透水性低下領域の外周に 大きな間隙水圧が作用し，その結果注入域における間 隙水圧が低下することを確認した。 また, 注入域の間 隙水圧が低下し, 有効応力が上昇するため, 塑性域に あったものが弾性域に移行するケースもあった. この ケースは, 注入域が拡大するような現象であり, 安全 側に作用すると言える.

注入域の全体で一様に透水性が低下したモデルを考 えるケース 3 では, 注入域全体で透水性が一様に低下 
すると注入域の間隙水圧は上昇するが，わずかずつで あるので, 有効応力の変化はほとんどない.

以上 3 つのケースの数值計算結果より, 湧水量の減 少によってトンネル覆工に関しては健全性に問題は生 じないという結論が得られた．本研究の成果は，時間 に依存した周辺地盤の透水性低下を考慮した解析によ り，海底トンネルの健全性を評価できた点にある．本 研究で透水性を低下させたのは 1 つの考えであり, 涌 水量減少の原因をすべて考慮できた訳ではない：排水 機能の低下などもその原因となりうるであろう。また, 覆工や地盤のモデル化, 境界条件の設定, 強度や剛性 といった物性值など検討すべき点は残されている．例 えば，本論文では注入域の弾性係数を周辺地盤と同じ 值と仮定したが，一般に薬液注入により剛性は上昇す る. 剛性の違いは有効応力の変化に大きな違いを与え る可能性がある．他にも，トンネルの経時劣化による 強度低下なども考慮する必要がある。

今後はこの点を考慮し, 様々な状況を想定し, 健全 性評価を行なっていくことが必要であると考える．ま た, 涌水量低下の要因の究明や健全性予測の解析をす るためにも，ボーリングなどの調査でトンネルの物性 值を詳細に調べる必要があると考えている.

謝辞： 京都大学故田村武先生からはトンネルの力学 について有益なアドバイスをいただいた。また，本研 究の一部は科学研究費 (基盤研究 (B) No. 21360223) に よった。ここに謝意を表す。

\section{参考文献}

1）足立紀尚, 田村武：高圧湧水下のトンネル工における水 抜孔の効果と注入域の適正規模, 土木学会論文・報告集, Vol. 280, pp. 87-98, 1978.

2) 土谷幸彦, 倉川哲志, 工藤健, 小西真治, 小島芳之, 東畑郁 夫 : 海底トンネルの覆工の長期挙動と評価に関する研究, 土木学会論文集 C, Vol. 63, No. 3, pp. 825-834, 2007.

3) 丹生和宏, 西藤潤, 田村武: 海底トンネルの健全性評価 に関する基礎的研究, トンネル工学論文集, Vol. 19, pp. 21-28, 2009.

4) 北村章, 柴田陽一: 青函トンネル海底部の注入および支保 の設計とその効果, 土と基礎; Vol. 36(7), pp. 37-42, 1988.

5) 田中忠次: 有限要素法による変形・安定解析 (主として砂 質土を対象にして), わかりやすい土質力学原論 [第 1 回 改訂版], 地盤工学会, 1992.

6) 吉川大三, 坂井五郎, 高橋正義, 木村裕俊, 先山友康: 青函 トンネル維持管理における内空断面測定, トンネル工学 研究発表会論文報告集, Vol. 6, pp. 211-216, 1996.

7) 例えば, 吉田秀典, 宇田圭一: 圧縮荷重下に扔けるコンク リートの破壊領域の形成に関する一考察, 構造工学論文 集, Vol. 50A, pp. 935-942, 2004.

8) 矢萩秀一, 入江健二, 大門信之, 中村兵次, 鈴木久尚 : 施 工過程を考慮したシールドトンネル覆工の応力計算方法, 土木学会論文集 F, Vol. 65, No. 2, pp. 128-147, 2009.

9) 永井哲夫, 張玉軍, 小谷野康之: 有限要素法によるトンネ ル掘削解析における掘削および地山のモデル化について, トンネル工学研究発表会論文報告集, Vol. 7, pp. 99-104, 1997.

10) 土木学会トンネル工学委員会 (編): 山岳トンネルに扔け る模型実験と数值解析の実務 (トンネル・ライブラリー), 土木学会, 2006 .

(2011. 6. 6 受付)

\title{
Numerical evaluation of the effect of permeability decrease on the undersea tunnel
}

\author{
Jun Saito, Kazuhiro NIU, Kiyoshi KISHIDA, Narutoshi FUKAZAWA
}

\begin{abstract}
It is reported that the amount of the seepage water measured in an undersea tunnel has been decreasing. The decrease of the seepage water is preferable in the view of tunnel maintenance. However, it can change the pore water pressure in the surrounding ground and reduce the safety of the lining. Therefore, we evaluate numerically soundness of the undersea tunnel by the soil-water coupled finite element analysis. We assume that the permeability decrease in surrounding ground is the reason for the decrease of seepage water and consider three cases. It is concluded that there is possibility that the permeability leads change of pore water pressure or expansion of plastic zone.
\end{abstract}

